\title{
School Water Policies
}

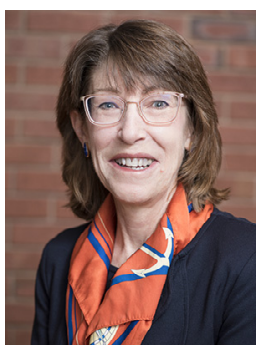

We know that water is important for health. A New Resource review for Water: The Foundation of a Healthy Body $^{1}$ is a good example of educational material we can use to spread the word. But it was the article in this issue by Sharma et al on the Strength and Comprehensiveness of Drinking Water Language in California School District Wellness Policies ${ }^{2}$ that prompted me to wonder about water fountains in schools during this resurgence in COVID transmissions and with many children back to face-to-face instruction. Part of the drinking water policy evaluation looked at water access, promotion, and water quality checks. The article also pointed out that water during the school day is important to children's health. School Wellness Policies can contribute to healthy water intake while at school.

But what about now? I still am wondering about those water fountains. I did a little searching, not exhaustive, but I found little information about water fountains in schools during the pandemic. Anecdotally, I know many were turned off and covered to prevent access. Before the pandemic, concerns about lead in the water, $^{3}$ functioning water fountains, and cleanliness of fountains have been published. ${ }^{4}$ An excellent review of drinking water in the United States provides background, context, and suggestions for improving water intake. ${ }^{5}$ And we know that hard surfaces have been found to have little conveyance of the COVID virus. $^{6}$ Interestingly, the $\mathrm{CDC}$ has guidelines for reopening water systems after prolonged shutdown ${ }^{7}$ as well as for cleaning and disinfection, ${ }^{8}$ but little on school water fountains in particular.
Are refillable water bottles the answer? One study in Austria reported that providing refillable water bottles increased water intake in third-grade students but the control school students also increased water intake. The authors concluded that the measurement in drinking habits may have provided the attention needed to motivate increased water intake. ${ }^{9}$ While this more simplistic approach may work, I found the Aquatic Program very interesting not only for its sustainability perspective in decreasing disposable water bottles but also for the intervention based on the Multiple Phase Optimization Strategy (MOST) ${ }^{10}$ and the theoretical model of Comprehensive Action Determination Model (CADM). ${ }^{11}$ I haven't seen this intervention strategy or theoretical model used much in the manuscripts we receive at JNEB, but I plan to do some additional reading. I encourage you to as well.

I will keep looking into the school water issues during the pandemic. If any of you have more information, please send me a line.

Karen Chapman-Novakofski, PhD, RDN

Editor-in-Chief

\section{REFERENCES}

1. Garden-Robinson J. Water: the foundation of a healthy body. J Nutr Educ Behav. 2019;51:1028-1029.

2. Latham S, Jennings JL. Reducing lead exposure in school water: evidence from remediation efforts in New York City public schools. Environ Res. 2021;203:111735

3. Kenney EL, Gortmaker SL, Cohen JF, Rimm EB, Cradock AL. Limited school drinking water access for youth. $J$ of Adolesc Health. 2016;59:24-29.

4. Patel AI, Hecht CE, Cradock A, Edwards MA, Ritchie LD. Drinking water in the United States: Implications of water safety, access, and consumption. Annu Rev Nutr. 2020;40:345-373.

5. Harvey AP, Fuhrmeister ER, Cantrell M, Pitol AK, Swarthout JM, Powers JE, Nadimpalli ML, Julian TR, Pickering AJ. Longitudinal monitoring of SARS-CoV-2 RNA on high-touch surfaces in a community setting. Environ Sci Technol Lett. 2021;8:168-175.

6. Center for Disease Control and Prevention. Reopening buildings after prolonged shutdown or reduced operation. 2021. https://www.cdc.gov/nceh/ehs/ water/legionella/building-water-system. html. Accessed August 23, 2021.

7. Center for Disease Control and Prevention. Guidance for COVID-19 prevention in K-12 schools. 2021. https://www.cdc.gov/coronavirus/ 2019-ncov/community/schools-childcare/k-12-guidance.html\#cleaningdisinfection. Accessed August 23, 2021.

8. Griebler U, Titscher V, Weber M, Affengruber L. Evaluation of the ' $\mathrm{H} 2 \mathrm{NOE}$ Water Schools' programme to promote water consumption in elementary school children-a non-randomised controlled cluster trial. Public Health Nutr. 2021. (online ahead of print).

9. Truskauskaitė-Kunevičiené I, Kaniušonytė G, Poškus MS, Balundè A, Gabe V, Jovarauskaite L, Özdemir M. Reducing bottled water use among adolescents: a factorial experimental approach to testing the components of the "aquatic" program. Sustainability. 2021;13:6758.

10. Collins LM, Murphy SA, Strecher V. The Multiphase Optimization Strategy (MOST) and the Sequential Multiple Assignment Randomized Trial (SMART): new methods for more potent eHealth interventions. Am J Prev Med. 2007;32:S112-S118.

11. Klöckner CA, Blöbaum AA. Comprehensive action determination model: toward a broader understanding of ecological behaviour using the example of travel mode choice. J Environ Psychol. 2010;30:574-586 